IRSTI 06.71.07

UDC 338.43

https://doi.org/10.46914/1562-2959-2021-1-3-143-150

\author{
K. YUKSEL, *1 \\ $\mathrm{PhD}$ student. \\ *e-mail: Kadiryuksel@live.com \\ S.S. YDYRYS, ${ }^{1}$ \\ d.e.s., professor. \\ e-mail: serikbay-s@mail.ru \\ MUSTAFA NURSOY, \\ professor. \\ e-mail: mustafanursoy@mu.edu.tr
}

B.A. SANDYBAYEVA, ${ }^{3}$

Master of economic sciences,senior lecturer.

e-mail: balzhan_s@list.ru

${ }^{1}$ Khoja Ahmed Yasawi International

Kazakh-Turkish University,

Kazakhstan, Turkestan

${ }^{2}$ Muğla Sitki Koçman University

Dean Of The Faculty Of Engineering, Turkey, Muğla

${ }^{3}$ Kazakh University of Economics,

Finance and International Trade,

Kazkahstan, Nur-Sultan

\title{
AIC IN THE FRAMEWORK OF IMPLEMENTING THE GOALS OF SUSTAINABLE DEVELOPMENT AND STATE POLICY FOR FORMATION AND DEVELOPMENT OF A COMPETITIVE INDUSTRY
}

\begin{abstract}
The article deals with the role of the agrarian sector in the socio-economic development of the country, in ensuring its export orientation and competitiveness in the conditions of the necessity to meet the requirements of the UN Sustainable Development Goals. Consequently, agriculture is an integral and important sector of the national economy and the main long-term priority of state economic policy, as the agro-industrial complex provides one of its most important components is the food security of the country. Meeting the country's demand for food, as well as ensuring food production with agricultural raw materials are the most important tasks of state policy. Besides ensuring the country's domestic market the agrarian sector should focus on its competitiveness and possibility to enter world markets in order to export its own production. One of the most important functions of public administration is the implementation of control and supervisory functions of the state for all types of activities of economic entities, whose purpose is to protect the rights and legitimate interests of state bodies, individuals and legal entities. In conditions of economic instability the search of optimal way of sustainable development of agrarian market of the Republic of Kazakhstan, able to provide food and economic security of the state, preserve and strengthen national independence of the country is of particular importance. However, for this purpose it is necessary to evaluate the development of the agrarian market for years of independence and identify the most urgent problems and factors that hinder its sustainable development. In this regard, new mechanisms of state regulation of the industry are required, ensuring the transition of the country's agro-industrial complex to a new innovative level of development.
\end{abstract}

Key words: economy, agro-industrial complex, agriculture, export, products, import, development.

\section{Literature review}

Political and socio-economic changes in the economy had an undoubted influence on the development of the country's agro-industrial complex, which influenced the level and structure of consumption of agricultural products. This, in turn, led to the formation of the consumer market, which is characterized by the saturation of the market with goods depending on the demand and price of goods. Thus, the share of spending on consumer goods increased, which led to a limited budget of the population. In this regard, there is a need for state support of the agro-industrial complex. The works of domestic and foreign scientists are devoted to the problems of state support of the agroindustrial complex. 
The works of domestic and foreign economists are devoted to the issues of improving state support of agricultural producers: A.A. Abalkin, N.A. Aldabergenov, J.B. Balapanov, V.V. Grigoruk, A.G. Zeldner, K.A. Sagadiev, G.A. Kaliev, J.K. Korgasbaev, T.I. Yespolov, A.A. Satybaldin, O. Sabden, M.I. Sigiraev, E.S. Savas, J.N. Sadu, O.K. Eskaraev, M.G. Isaeva, A.E. Kovalev, A.B. Moldashev, M.A. Sazhina, U.K. Kerimova, L. Leutsky, J. Sundetov, P.P. Shevchik, A. Chelekbay, Koshanov A.K., Kantarbayeva Sh.M., Smagulova Sh.A., Gamarnik G.N., etc.

The works of these authors reveal conceptual approaches, methodological and methodological foundations, as well as the main ways and directions of formation of the economic mechanism of economic activity in agriculture with active state intervention.

However, despite the active development of the above-mentioned issues, today there are still certain gaps in the theoretical and methodological aspects of state regulation and support of agricultural producers, and in particular - in the sphere of animal husbandry. Modern requirements were caused the needs for state regulation and support of domestic agricultural producers, which imposes WTO. In this regard, given the current realities in the economy, in particular changes in agriculture, determine the need for deepening research on this issue.

\section{Introduction}

One of the most important functions of public administration is the implementation of control and supervisory function of the state for all types of activities of economic entities, the purpose of which is to protect the rights and legitimate interests of state bodies, individuals and legal entities. The system of state audit and financial control is an integral attribute of state power. Improvement of its efficiency contributes to strengthening of financial, budgetary and tax discipline. Response measures, taken by the results of audits and evaluations, allow reducing promptly the material and financial damage to the state, its citizens and the natural environment.

In the conditions of economic instability the search of optimal way of sustainable development of agrarian market of the Republic of Kazakhstan, which is able to provide food and economic security of the state, preserve and strengthen national independence of the country acquires particular importance. However, for this purpose it is necessary to evaluate the development of the agrarian market for years of independence and identify the most urgent problems and factors that hinder its sustainable development. In this connection new mechanisms of state regulation of the branch, providing transition of agro-industrial complex of the country to a new innovative level of development, are required.

To date, the main problem of competitive development of the economy of any state is to ensure the self-sufficiency of the national economic system, which is achieved by ensuring the progressive systematization of its main elements, which interact harmoniously with each other.

The main elements are sectors of the economy, among which strategic and focused on ensuring the integrity of the economy of the country is agro-industrial complex, which is a complex, multibranch production and economic system and is one of the most important elements of the system of economic security of the country, including food.

Consequently, the further development of agriculture is one of the main strategic tasks of state policy, where the state of agro-industrial complex for today is characterized by insufficient level of development, technological backwardness, significant physical and moral deterioration of material and technical base of agricultural sector.

Significant attention is paid to the development of the agro-industrial complex in the framework of the Sustainable Development Goals (hereinafter - SDGs) - the document "Transforming our world: a sustainable development agenda for the period up to 2030". The SDGs are a UN document, adopted and signed by the heads of member states in September 2017 at the UN summit at the 70th General Assembly of the United Nations, including the President of the Republic of Kazakhstan N.A. Nazarbayev. Therefore, it confirms the need for compliance of priorities and objectives of the country's development with the goals and benchmarks of the SDG [1]. This document also concerns the agro-industrial complex, in particular goal 2 "End hunger, food security and better nutrition, promote sustainable development of rural areas".

\section{Methodology}

The methodological basis of this study was the fundamental works in the field of assessing the economic efficiency and impact of the agrarian sector on the economic development of the state, as 
well as scientific articles in leading economic journals of domestic and foreign scholars on the problem under study. The works generalizing the achievements of the world economic literature concerning the issues of financing and crediting of agro-industrial complex are widely used.

During the systematization, study and analysis of the accumulated material, both theoretical and practical, the complex of general scientific principles and methods used in economic research, including systemic approach, structural and functional analysis of the state and development of agriculture of the country were used. In addition, analytical, graphic, economic-statistical, abstractlogical, comparative and other methods of research were used.

\section{Results and discussion}

To implement the SDGs related to the agro-industrial complex and to establish the achievement of the goal, the indicator "Agriculture Oriented Index (AOI)" is calculated as the ratio of the share of agriculture in public expenditures to the share of agriculture in GDP, which depends on the structure of public expenditures of the country (Table 1).

Table 1 - Agricultural orientation index based on the structure of public expenditures under the SDGs

\begin{tabular}{|l|c|c|c|}
\hline \multicolumn{1}{|c|}{ Countries } & 2017 & 2018 & 2019 \\
\hline Azerbaijan & 0,5 & 0,6 & 0,5 \\
\hline Armenia & 0,1 & 0,1 & 0,1 \\
\hline Belarus & 1,3 & 1,1 & 0,8 \\
\hline Kazakhstan & 0,9 & 0,9 & 0,8 \\
\hline Kyrgyzstan & $\ldots$ & $\ldots$ & $\ldots$ \\
\hline Moldova & 0,4 & $\ldots$ & $\ldots$ \\
\hline Russia & 0,3 & 0,3 & 0,3 \\
\hline Tajikistan & 0,1 & 0,1 & 0,2 \\
\hline Uzbekistan & $\ldots$ & $\ldots$ & $\ldots$ \\
\hline Ukraine & $\ldots$ & $\ldots$ & $\ldots$ \\
\hline Note - Compiled from [2]. & \multicolumn{2}{|l}{} \\
\hline
\end{tabular}

A significant size of this indicator is observed in Belarus for the CIS countries, which, however, since 2017, tends to decrease from 1.3 to 0.8 in 2019. Also indicator - AOI insignificantly decreased and for Kazakhstan from 0.9 in 2017 to 0.8 in 2019. This indicator reflects the allocation of funds from the budget to support agriculture in the country.

It can be noted that Kazakhstan is traditionally an agricultural country on this basis, where the agricultural population is more than $40 \%$ of the population of the country (Table 2), which is also confirmed by the SDG indicator, reflecting the allocation of significant funds of state support for the development of the agricultural sector.

Table 2 - Population of the Republic of Kazakhstan for 2012-2019, thousand people

\begin{tabular}{|l|c|c|c|c|c|c|c|c|}
\hline Region & 2012 & 2013 & 2014 & 2015 & 2016 & 2017 & 2018 & $2019 \Gamma$ \\
\hline & 16203,3 & 16440,5 & 16674, & 16910,2 & 17160,9 & 17415,7 & 17669,9 & 17918,2 \\
\hline Total & 7383,6 & 7466,5 & 7546,4 & 7632,4 & 7578,7 & 7634,3 & 7668,1 & 7733,8 \\
\hline Rural areas & 45,6 & 45,4 & 45,3 & 45,1 & 44,1 & 43,5 & 43,8 & 43,2 \\
\hline
\end{tabular}

At the same time, there is a tendency of decrease in the share of population living in rural areas from $45.6 \%$ in 2012 to $43.2 \%$ in 2019 .

There is a similar decrease in the indicator that characterizes the employment of the population in the context of industries. In particular, the share of those employed in agriculture decreased from $28.3 \%$ in 2012 to $14.1 \%$ in 2020 , which may indicate a decrease in the number of jobs in the agricultural sector and a decrease in interest in the agricultural sector (Table 3, p. 146). 
Table 3 - Population employed in agriculture in 2012-2020, thousand people

\begin{tabular}{|l|c|c|c|c|c|c|c|c|c|}
\hline \multicolumn{1}{|c|}{ Name } & 2012 & 2013 & 2014 & 2015 & 2016 & 2017 & 2018 & 2019 & 2020 \\
\hline $\begin{array}{l}\text { Employed in } \\
\text { the economy, } \\
\text { total }\end{array}$ & 8114,2 & 8301,6 & 8507,1 & 8570,6 & 8510,1 & 8433,3 & 8553,4 & 8585,2 & 8695,0 \\
\hline $\begin{array}{l}\text { Agriculture, } \\
\text { forestry and } \\
\text { fishery }\end{array}$ & 2294,9 & 2196,1 & 2172,7 & 2073,6 & 1605,1 & 1362,9 & 1385,5 & 1319,0 & 1228,2 \\
\hline $\begin{array}{l}\text { Share of } \\
\text { workers in } \\
\text { agriculture, } \\
\text { forestry, and } \\
\text { fisheries }\end{array}$ & 28,3 & 26,5 & 25,5 & 24,2 & 18,9 & 16,2 & 16,2 & 15,4 & 14,1 \\
\hline
\end{tabular}

In developed countries there is also a downward trend in the number of people employed in this sector of the economy, which is explained by the accelerated development of industrial-innovative spheres of the economy, as well as the growth of labor productivity in agriculture itself. In the early 2000 s the share of the employed in the primary sector (as a \% of the total number of the employed) was: in the USA - 2.6, Germany - 2.7, Great Britain - 1.4, Canada - 3.3, Japan - 5.1. Accordingly, in the countries with transitional and developing economies this share is higher and amounts to: in Russia $12.7 \%$ of the employed population, in Ukraine - 23.6, in Poland - 18.8, China - 46.8, Pakistan - 47.3, Indonesia $-43.2 \%$.

Despite the declining share of those employed in agriculture, this sector in Kazakhstan is one of the key sectors of the country's economy, which allows to ensure food security almost completely, and to export agricultural products abroad. Consequently, the agricultural sector has always been and continues to be a determining factor in the economic and socio-political stability of Kazakh society. At the same time, there has been a slight decrease in its share of GDP during the period from 2009 to 2019 , varying between $4.7-5.5 \%$ (Table 4). According to Statistics Committee, this indicator was about $4.3 \%$ in 2020 .

Table 4 - Share of agriculture in GDP, \%

\begin{tabular}{|l|l|c|c|c|c|c|c|c|c|c|}
\hline № & Name & 2009 & 2012 & 2013 & 2014 & 2015 & 2016 & 2017 & 2018 & 2019 \\
\hline 1 & Russia & 4,2 & 3,5 & 3,9 & 3,7 & 3,6 & 4,1 & 4,3 & 4,3 & 4,7 \\
\hline 2 & Indonesia & 14,3 & 14,3 & 13,8 & 13,7 & 13,7 & 13,7 & 13,9 & 14,0 & 13,7 \\
\hline 3 & Brazil & 5,2 & 4,8 & 5,1 & 4,9 & 5,3 & 5,0 & 5,0 & 5,1 & 6,6 \\
\hline 4 & India & 18,4 & 18,9 & 18,5 & 18,2 & 18,6 & 18,0 & 17,5 & 17,4 & 15,4 \\
\hline 5 & China & 10,1 & 9,8 & 9,7 & 9,7 & 9,6 & 9,3 & 9,1 & 8,9 & 7,9 \\
\hline 6 & USA & 0,96 & 1,1 & 1,3 & 1,2 & 1,3 & 1,2 & 1,0 & 0,95 & 0,9 \\
\hline 7 & Canada & 1,5 & 1,4 & 1,7 & 1,8 & 1,8 & 1,5 & 1,7 & 1,7 & 1,6 \\
\hline 8 & Belarus & 9,4 & 10,1 & 9,1 & 9,3 & 7,7 & 8,3 & 7,2 & 8,0 & 8,1 \\
\hline 9 & \multicolumn{9}{|l|}{ Kazakhstan } \\
\hline \multicolumn{7}{|l|}{ Note } \\
\hline
\end{tabular}

According to Table 4, agriculture has a significant share in the economies of such countries as India, Indonesia, China and Belarus, which are exporters of agricultural products.

At the same time, it should be noted that the main exporting countries are the USA, Russia, Brazil, Canada, which have a low share of agriculture in GDP of about $1-6 \%$.

For example, in the US the structure of the economy consists of services $-78 \%$, industry $-21 \%$ and agriculture $-1 \%$. The U.S. is in the top 10 countries in terms of agricultural exports, in particular, it ranks first in soybeans production, third in sugar beets, ninth in cane harvesting and 11th in rice harvesting.

Thus, agriculture in the United States, regardless of its share in the country's GDP (1\%), has a high level of development and is a competitive industry, due to a combination of science, agricultural production, processing of agricultural raw materials, transportation and marketing of products. 
Agriculture in Kazakhstan, despite its low share in the national GDP, has a high socio-economic importance and remains a very important branch of the country's economy, since more than $40 \%$ of the population lives in rural areas. Thus, in the structure of the country's GDP by type of economic activity, agriculture occupied: in $2020-4.3 \%$, in $2005-6.5 \%$ in 2005 , and $8.1 \%$ in $2000-8.1 \%$, and in $1990-34 \%$.

Peasant (private) farms and agricultural enterprises occupy the largest share in the structure of gross crop production in $2020-71 \%$. Households account for $67 \%$ in the structure of gross livestock production.

The volume of gross agricultural production increases annually and amounts to 4,376.8 billion tenge in 2020. In comparison with 2016 this indicator increased by almost $40 \%$, and in comparison with 2014 - by $83 \%$.

In the structure of gross production, 53.3\% accounts for crop production, $46.7 \%$ - livestock.

Despite the positive trends in the industry, agriculture in Kazakhstan is characterized by low labor productivity due to low crop yields and low productivity of farm animals, as well as the use of outdated labor-intensive technologies, weak innovation activity of the industry entities, which is reflected in the unattractiveness of the industry for investment. Thus, the share of agriculture in the total volume of investment in 2020 was $3.5 \%$, in $2016-2.6 \%$.

The industry needs to update agricultural equipment, which has a high level of wear and tear. Most of the agricultural machinery was manufactured before 1991. The annual rate of renewal of agricultural machinery in the country is about $1.5-2 \%$, which is significantly lower than the analogous indicator in Russia $-4 \%$ and in OECD countries, which is about $10-12 \%$.

At the same time, investment in agriculture 2020 increased by $14.2 \%$ compared to the previous year and amounted to 395,6 billion tenge.

In addition to agriculture, the agricultural sector also includes the sector related to food production, which until 2018 showed a tendency to increase the volume of food production, and in 2019-2020 its insignificant changes. Thus, the volume of food production increased 1.8 times by 2020 compared to 2013.

The support measures implemented through state and government development programs have a significant impact on this industry, which is reflected in an increase in investment in fixed assets. Thus, in 2020, investments invested in the production of products increased by 3.6 times compared to 2013 .

Today, Kazakhstan has a great potential for the production of agricultural products, but food imports (40\%) occupy a significant share, and the industry itself is not developing fast enough.

Over the past four years, the volume of exports in physical terms has increased by $72.6 \%$, while imports have also increased, growing by about $9 \%$ over the same period.

In monetary terms, exports and imports also increased by $36.6 \%$ and $4.6 \%$, respectively.

At the same time, in terms of exports of types of agricultural products, significant changes in the dynamics downward by2020 compared to the previous year occurred in the following analyzed positions:

- "poultry eggs, in shell, fresh, canned or boiled" from $232.5 \%$ to $172.3 \%$;

- "butter and other fats and oils made from milk, milk paste" from $202.6 \%$ to $133.7 \%$;

At the same time, a significant increase in export volumes by 2020 according to changes occurred in the context of commodity positions - "cattle meat, fresh or chilled" and "butter and other fats and oils made from milk, milk pastes", which amounted to more than 6 times.

In general, for all commodity positions of agricultural products for three years there was a downward trend in the volume of exports from $136.3 \%$ to $110.6 \%$.

In terms of import types of agricultural products, significant changes in the downward trend for 2019 compared to 2018 occurred for export items:

- "butter and other fats and oils made from milk, milk pastes" from $117.1 \%$ to $79.1 \%$;

- "sunflower, safflower or cotton oil and their fractions, unrefined or refined, but without changing the chemical composition" from $86.9 \%$ to $80.2 \%$.

At the same time, imports of the following items increased significantly in dynamics:

- "bovine meat, fresh or chilled" from $106.4 \%$ to $793.2 \%$;

- "wheat or wheat and rye flour" from $39.2 \%$ to $117.1 \%$.

- "Bird eggs, in shell, fresh, canned or boiled" from $108 \%$ to $156.9 \%$.

In terms of the volume of imports, there were no significant fluctuations in 2020 in relation to 2019, except for the position - "cattle meat, fresh or chilled", which decreased by almost 8 times. 
In general, there were no significant fluctuations in all commodity items of agricultural products for the last two years, except for two items - "cattle meat, fresh or chilled" and "butter and other fats and oils made from milk, milk pastes". A $10 \%$ decrease in imports was observed in the previous year, 2019.

Based on the above, it follows that for 2018-2020, there is a positive trend in the difference in the decrease in the volume of imports of agricultural products compared to the rate of decrease in the volume of exports of agricultural products.

Thus, the development of the agricultural sector of the country depends largely on the consistent implementation of public policy aimed at the formation and development of competitive and exportoriented agricultural industry, corresponding to world benchmarks, since Kazakhstan has all the advantageous conditions for this: the vast areas of agricultural land, industry specialization, proximity to major markets and, most importantly, the availability of funds obtained through government support measures in the form of subsidies.

\title{
REFERENCES
}

1 UN in Kazakhstan-URL:http://kz.one.un.org/content/unct/kazakhstan/ru/home/mdgs-sdgs/sustainabledevelopment-goals.html

2 Monitoring of SDG indicators in the CIS region 2017-2019 // Statistical abstract MOSCOW2019 MONITORING OF SDG INDICATORS IN THE CIS REGION 2017-2019.

3 Bureau of National Statistics Agency for Strategic Planning and Reformshttp: //stat.gov.kz/

4 Republic of Kazakhstan Macroeconomic research. - URL: http://be5.biz/makroekonomika/agriculture/ ca.html

5 UNECE. - URL: https://w3.unece.org/PXWe

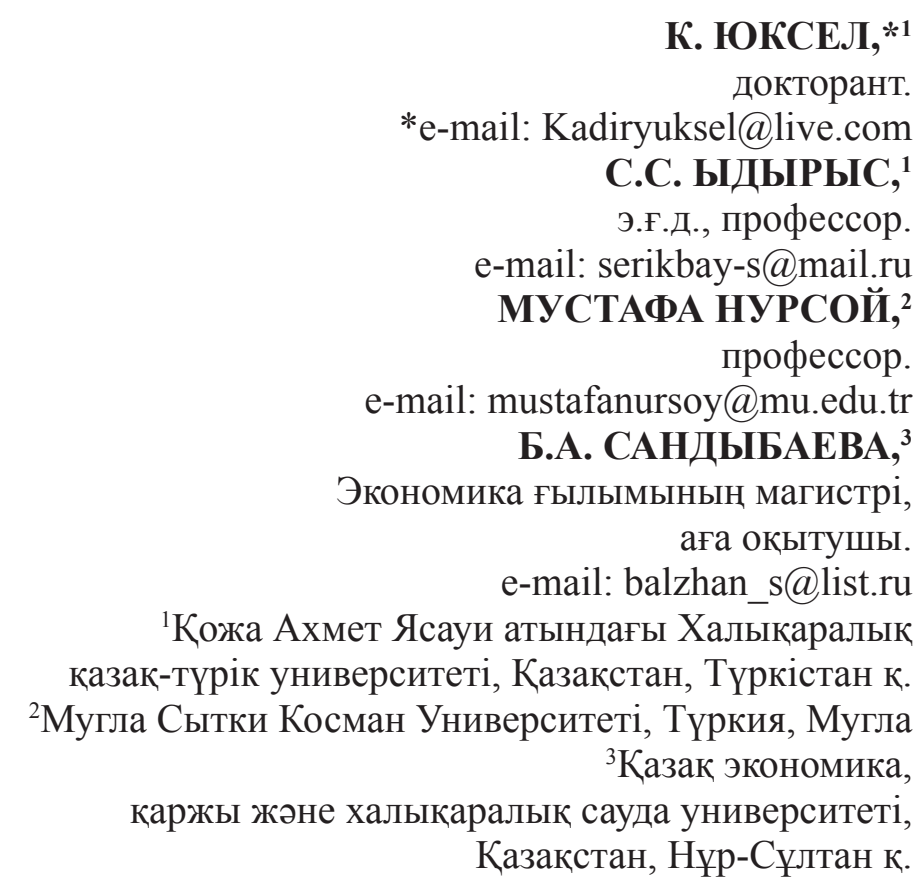

\author{
АӨК ОРНЫҚТЫ ДАМУ МАКСАТТАРЫН \\ ЖӘНЕ БӘСЕКЕГЕ КАБІЛЕТТІ САЛАНЫ ҚАЛЫПТАСТЫРУ \\ ЖӘНЕ ДАМЫТУ ЖӨНІНДЕГІ МЕМЛЕКЕТТІК \\ САЯСАТТЫ ІСКЕ АСЫРУ ШЕНБЕРІНДЕ
}

\section{Андатпа}

Мақаланың мақсаты - аграрлық саланың елдің әлеуметтік-экономикалық дамуындағы, БҰҰ-ның тұрақты даму Мақсаттарының талаптарына сәйкес болу қажеттілігі жағдайында оның экспортқа бағдарлануы мен бәсекеге қабілеттілігін қамтамасыз етудегі рөлін қарастыру. Демек, агроөнеркәсіп кешені елдің ма- 
ңызды компоненттерінің бірі - азық-түлік қауіпсіздігін қамтамасыз ететіндіктен, ауыл шаруашылығы - ел экономикасының ажырамас, маңызды саласы және мемлекеттік экономикалық саясаттың негізгі ұзақ мерзімді басымдығы болып табылады. Еліміздің азық-түлікке деген қажеттіліктерін қанағаттандыру, сондайақ азық-түлік өндірісін ауылшаруашылық шикізатымен қамтамасыз ету - мемлекеттік саясаттың маңызды міндеттері болып табылады. Елдің ішкі нарығын қамтамасыз етуден басқа, аграрлық сала өзінің бәсекеге қабілеттілігін және өз өнімін экспорттау мақсатында әлемдік нарықтарға шығу мүмкіндігін қамтамасыз етуге бағдарлануы тиіс. Мемлекеттік басқарудың маңызды функцияларының бірі - бұл мемлекеттік органдардың, жеке және заңды тұлғалардың құқықтары мен заңды мүдделерін қорғау мақсатында, шаруашылық жүргізуші субъектілер қызметінің барлық түрлеріне мемлекеттің бақылау және қадағалау функциясын жүзеге асыру. Экономикалық тұрақсыздық жағдайында мемлекеттің азық-түлік және экономикалық қауіпсіздігін қамтамасыз етуге, елдің ұлттық тәуелсіздігін сақтауға және күшейтуге қабілетті Қазақстан Республикасының аграрлық нарығын орнықты дамытудың оңтайлы жолын іздестіру ерекше маңызға ие болуда. Алайда, бұл үшін тәуелсіздік жылдарындағы аграрлық нарықтың дамуына баға беріп, оның тұрақты дамуына кедергі келтіретін өзекті проблемалар мен факторларды анықтау қажет. Осыған байланысты, елдің агроөнеркәсіптік кешенінің дамудың жаңа инновациялық деңгейіне өтуін қамтамасыз ету үшін саланы мемлекеттік реттеудің жаңа тетіктері қажет.

Тірек сөздер: экономика, агроөнеркәсіптік кешен, ауыл шаруашылығы, экспорт, өнім, импорт, даму.

К. ЮКСЕЛ,*1 докторант.

*e-mail: Kadiryuksel@live.com С.С. ЫДЫРЫС, ${ }^{1}$ д.э.Н., профессор. e-mail: serikbay-s@mail.ru МУСТАФА НУРСОЙ, ${ }^{2}$ профессор. e-mail: mustafanursoy@mu.edu.tr

Б.А. САНДЫБАЕВА, ${ }^{3}$ магистр экономических наук, ст. преподаватель.

e-mail: balzhan_s@list.ru

${ }^{1}$ Международный казахско-турецкий университет им. Ходжа Ахмеда Ясави, Казахстан, г. Туркестан ${ }^{2}$ Университет Муглы Сытки Космана, Турция, Мугла

${ }^{3}$ Казахский университет экономики, финансов и международной торговли, Казахстан, г. Нур-Султан

\section{АПК В РАМКАХ РЕАЛИЗАЦИИ ЦЕЛЕЙ УСТОЙЧИВОГО РАЗВИТИЯ И ГОСУДАРСТВЕННОЙ ПОЛИТИКИ ПО ФОРМИРОВАНИЮ И РАЗВИТИЮ КОНКУРЕНТОСПОСОБНОЙ ОТРАСЛИ}

\footnotetext{
Аннотация

Цель статьи - рассмотреть роль аграрной отрасли в социально-экономическом развитии страны, в обеспечении ее экспортоориентированности и конкурентоспособности в условиях необходимости соответствия требованиям Целей устойчивого развития ООН. Следовательно, сельское хозяйство является неотъемлемой и важной отраслью экономики страны и основным долгосрочным приоритетом государственной экономической политики, так как агропромышленный комплекс обеспечивает одну из важнейших ее составляющих продовольственную безопасность страны. Обеспечение потребности страны в продовольствии, а также обеспечение производства продуктов питания сельскохозяйственным сырьем являются важнейшими задачами государственной политики. Кроме обеспечения внутреннего рынка страны аграрная отрасль должна ориентироваться на обеспечение своей конкурентоспособности и возможности выхода на мировые рынки с целью экспортирования собственной продукции. Одной из важнейших функций государственного управле-
} 
ния является осуществление контрольной и надзорной функции государства за всеми видами деятельности субъектов экономики, целью которой является защита прав и законных интересов государственных органов, физических и юридических лиц. В условиях экономической нестабильности особую значимость приобретают поиски оптимального пути устойчивого развития аграрного рынка Республики Казахстан, способного обеспечить продовольственную и экономическую безопасность государства, сохранить и усилить национальную независимость страны. Однако для этого необходимо дать оценку развитию аграрного рынка за годы независимости и выявить наиболее актуальные проблемы и факторы, препятствующие его устойчивому развитию. В этой связи требуются новые механизмы государственного регулирования отрасли, обеспечивающие переход агропромышленного комплекса страны на новый инновационный уровень развития.

Ключевые слова: экономика, агропромышленный комплекс, сельское хозяйство, экспорт, продукция, импорт, развитие. 